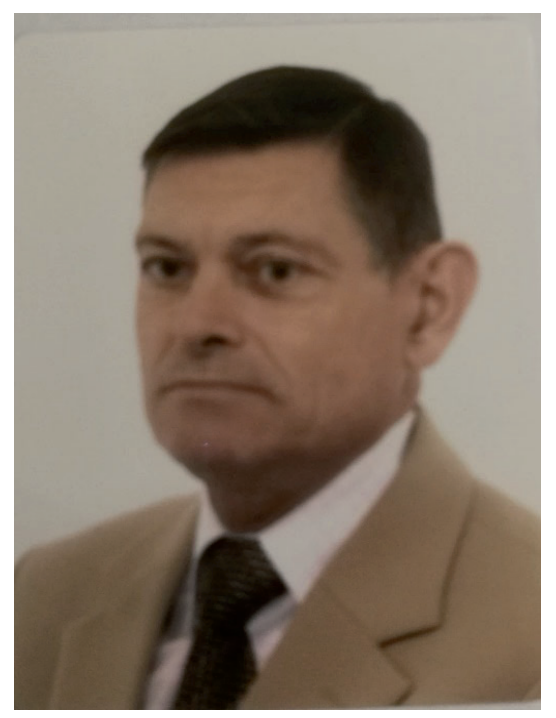

\title{
ONE OF THE BIOGRAPHIES OF AN AVIATION PHYSICIAN WORKING AT THE MILITARY INSTITUTE OF AVIATION MEDICINE
}

Witold BEDNARSKI

Source of support: Own sources

Author's address: W. Bednarski, Warsaw, Poland, e-mail: bednarski.witold@gmail.com
Abstract: The author presents a short story connected with working as an air doctor in a military unit and as a researcher in the Military Institute of Aviation Medicine in Warsaw in the Department of Aviation Safety. He also presents the procedures of examination of the anatomopathologist participating in the work of the commissions investigating air accidents and catastrophes.

Keywords: flight safety, aeronautical anatomopathology, investigation of air accidents and catastrophes 
I graduated from the Military Medical Academy in 1975 at the Faculty of Medicine with diploma number 1890. After a postgraduate internship, I was referred to the 34th Air Defense Division of the Country (OPK) Fighter Regiment in Gdynia as the Head of the Outpatient Department. In 1981 I started working at the Military Institute of Aviation Medicine (MIAM) in Warsaw as a senior assistant at the Institute of Flight Hygiene and Safety. The Department conducted scientific research related to the hygiene of flying and technical personnel concerning occupational hygiene, nutrition, uniforms, aeronautical toxicology, the impact of microwave radiation on the human body, as well as the causes of air accidents from the point of view of aviation medicine. MIAM set up a medical subcommittee for the Air Accident Investigation Committee (AAIC) of the Ministry of National Defense, where I worked for over 20 years as a specialist in forensic medicine. The medical subcommittee consisted of an aviation doctor, an aviation psychologist and a forensic specialist. I provided judicial and medical expert opinions based on the decision of the Air Force Prosecutor's Office. My tasks in AAIC included: determination of mechanisms and directions of traumatizing forces generated at the moment of collision of the plane with the ground, the possibility of fire and high temperature's impact on the pilot's body during the flight, as well as the assessment of the pilot's health, because the disease changes could result in a loss of consciousness and an air crash. Toxic factors (e.g. carbon monoxide, alcohol) and psychoactive agents were tested in biological material taken from the pilot. In my scientific activity I dealt with air and sea rescue. Many times I participated in scientific and training conferences in Poland and abroad, where I presented scientific papers. I dissolved the service relationship with the Ministry of National Defense in 2002.

\section{AUTHORS' DECLARATION:}

Study Design: Witold Bednarski; Data Collection: Witold Bednarski; Manuscript Preparation: Witold Bednarski. The Author declares that there is no conflict of interest.

Cite this article as: Bednarski W. One of The Biographies of an Aviation Physician Working at The Military Institute of Aviation Medicine. Pol J Aviat Med Bioeng Psychol 2017; 23(3-4): 106-107. DOI: 10.13174/pjambp.20.12.2018.15 